\title{
PERFORATED MONOLAYERS
}

Final Report

July 1,1985 - June 30,2000

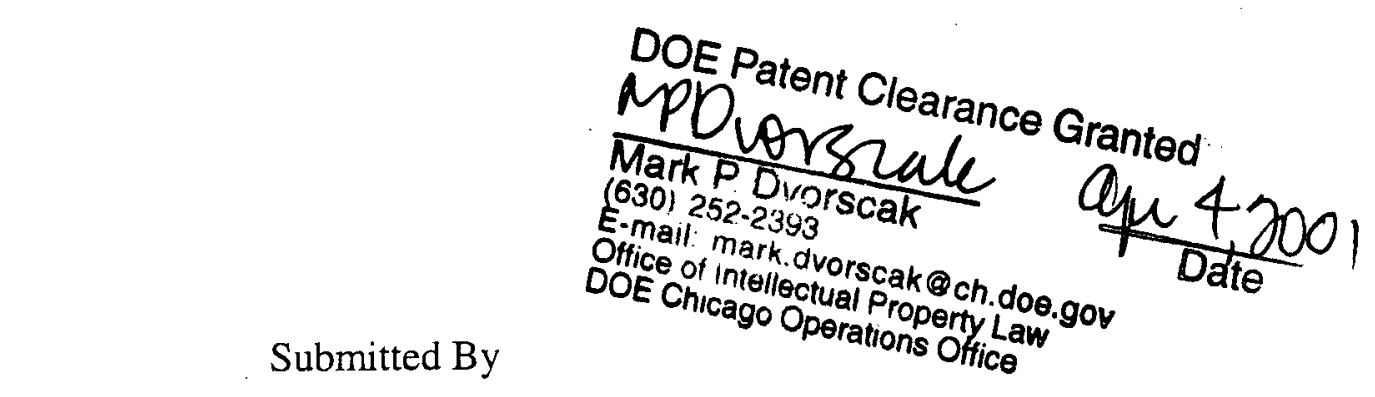

S. L. Regen

Department of Chemistry, Lehigh University

Bethlehem, Pennsylvania 18015

June, 2000

PREPARED FOR THE U.S. DEPARTMENT OF ENERGY

CONTRACT NUMBER DE-FG02-85ER13403 


\section{DISCLAIMER}

This report was prepared as an account of work sponsored by an agency of the United States Government. Neither the United States Government nor any agency thereof, nor any of their employees, makes any warranty, express or implied, or assumes any legal liability or responsibility for the accuracy, completeness, or usefulness of any information, apparatus, product, or process disclosed, or represents that its use would not infringe privately owned rights. Reference herein to any specilic commercial product, process, or service by trade name, trademark, manufacturer, or otherwise does not necessarily constitute or imply its endorsement, recommendation, or favoring by the United States Government or any agency thereof. The views and opinions of authors expressed herein do not necessarily state or reflect those of the United States Government or any agency thereof. 


\section{DISCLAIMER}

Portions of this document may be illegible in electronic image products. Images are produced from the best available original document. 



\section{SUMMARY}

The goal of this research program was to create ultrathin organic membranes that exhibit high permeability and high permeation selectivity toward gases. Such membranes were expected to provide the basis for energy-efficient methods of molecular separation. Work that was carried out during the course of this program focused on: (i) the design and synthesis of a wide variety of calix[n]arene-based surfactants, (ii) the characterization of the monolayer properties of these surfactants, (iii) the fabrication of composite membranes using Langmuir-Blodgett films derived from calix[n]arenes and a variety of organic polymeric supports, and (iv) the characterization of the permeation properties of the resulting composites.

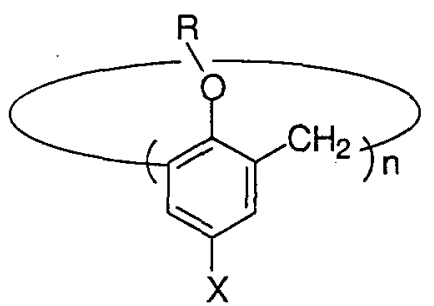

Calix[n]arene

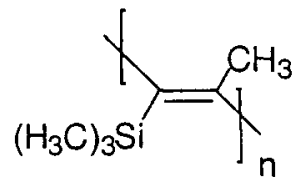

PTMSP

A major finding that came out of this effort was that Langmuir-Blodgett films can be used as ultrathin membranes for the separation of gases such as helium and nitrogen. The ultrathiness of the membrane separators $(<40 \AA)$ that were synthesized as part of this program was without precedent. Given the inverse relationship that exists between the flux of a permeant and the thickness of a membrane separator, this finding was of special signficance. A fundamental discovery that was made was the need to have the diameters of individual porous surfactants greater than the diameter the surface pores of the support, in order to create defect-free film. When the diameters of the porous surfactants were smaller in diameter, the resulting Langmuir-Blodgett film was found to undergo a disassembly process. In addition, unusual pressure effects were found with certain 
perforated monolayer films. In contrast to all known polymeric membranes, when the pressure gradient of permeant was increased, the normalized flux was found to increase in selected cases. The last publication in this series, which summarize these pressure effects, presents a model in which small molecules such as helium can diffuse through individual porous surfactants, as well as between neighboring calix[6]arene-surfactants. In contrast, larger permeants such as nitrogen are unable to pass through individual calix[6]arenes. Instead, permeation is largely confined to a pathway that runs between neighboring molecules.

The details of all of the work that has been carried out during the course of this program appears in the following publications:

\section{PUBLICATIONS ACKNOWLEDGING DOE SUPPORT UNDER GRANT DE-FG02-85ER13403}

1. M. A. Markowitz, R. Bielski, S. L. Regen, "Perforated Monolayers: Porous and Cohesive Monolayers From Mercurated Calix[6]arenes", J. Am. Chem. Soc., 110, 7545 (1988).

2. M. A. Markowitz, R. Bielski, S. L. Regen, "Ultrathin Monolayers and Vesicular Membranes From Calix[6]arenes", Langmuir, 5, 276 (1989).

3. M. A. Markowtiz, V. Janout, D. G. Castner, S. L. Regen, "Perforated Monolayers: Design and Synthesis of Porous and Cohesive Monolayers Derived From Mercurated Calixarenes, J. Am. Chem. Soc., 111, 8192 (1989).

4. M. Conner, I. Kudelka, S. L. Regen, "Octopus Molecules at the Air--Water Interface. Mechanical Control Over Tentacle Orientation", Langmuir, 7, 982 (1991).

5. M. Conner, V. Janout, S. L. Regen, "Pinched Cone-Conformers of Calix[4]arenes, J. Am. Chem. Soc., 113, 9670 (1991).

6. M. Conner, V. Janout, and S. L. Regen, "Synthesis and Alkali Metal Binding Properties of "UpperRim" Functionalized Calix[4]arenes", J. Org. Chem., 57, 3744 (1992).

7. M. Conner, S. L. Regen, "A Convenient Method For Measuring Pervaporation Through Monolayers At The Gas-Water Interface", Langmuir, 8, 2347 (1992).

8. M. Conner, V. Janout, S. L. Regen, "Molecular Sieving By A Perforated Langmuir-Blodgett Film", J. Am. Chem. Soc.; 115, 1178 (1993). 
9. M. D. Conner, V. Janout, I. Kudelka, P. Dedek, J. Zhu, and S. L. Regen, "Perforated Monolayers: Fabrication of Calix[6]arene-based Composite Membranes That Function As Molecular Sieves", Langmuir, 9, 2389 [1993].

10. P. Dedek, V. Janout, S. L. Regen, "Porous Surfactants From Cone Conformers Of Calix[5]arenes", J. Org. Chem., 58, 6553 (1993).

11. P. Dedek, A. S. Webber, V. Janout, R. A. Hendel, S. L. Regen, "Probing The Pore Structure of Calix[n]arene-Based Langmuir-Blodgett Film By Gas Permeation Selectivity", Langmuir, 10, 3943 (1994).

12. M. D. Conner, S. L. Regen, "Perforated Monolayers", Advanced Materials, 6. 872 (1994).

13. Lee, W.; Hendel, R. A.; Dedek, P.; Janout, V.; Regen, S. L., "Membrane Composites Derived From Porous versus Nonporous Surfactants: Evidence for Uniqueness of Calix[6]arene-Based Surfactants", J. Am. Chem Soc., 117, 6793 (1995).

14. W. Lee, R. A. Hendel; P. Dedek, V. Janout, S. L. Regen, "Unusual Pressure Effects On The Permeation Properties Of A Langmuir-Blodgett Composite Membrane", J. Am. Chem. Soc., 117, 10599 (1995).

15. R. A. Hendel, V. Janout, W. Lee, S. L. Regen, "Extraordinary Cohesiveness Of A Boronic Acid Calix[6]arene Monolayer at the Air-Water Interface", Langmuir, 12, 5745 (1996).

16. R. A. Hendel, E. Nomura, V. Janout, S. L. Regen, "Assembly and Disassembly Of Langmuir-Blodgett Films On Poly[1-(trimethylsilyl)-1-propyne]: The Uniqueness of Calix[6]arene Multilayers As Permeation Selective Membranes", J. Am. Chem. Soc., 119, 6909 (1997).

17. R. A. Hendel, L-H. Zhang, V. Janout, M. D. Conner, J. T. Hsu, S. L. Regen, "Insight Into The Permeation Selectivity of Calix[6]arene-Based Langmuir-Blodgett Film: Importance of Head Group Association and the Solid Phase", Langmuir, 14, 6545 (1998).

18. L.-H. Zhang, R. A. Hendel, P. G. Cozzi, S. L. Regen, "A Single Langmuir-Blodgett Monolayer For Gas Separations", J. Am. Chem Soc., 121, 1621 (1999).

19. X. Yan, J. T. Hsu, S. L. Regen, "Selective Dampening of Gas Permeability of a LangmuirBlodgett Film Using Moist Permeants", J. Am. Chem. Soc., 122, 0000 (2000). 
